\title{
Hypovitaminosis D according to psychiatric diagnosis groups: A study with control group
}

\section{Psikiyatrik tanı gruplarına göre vitamin D eksikliği: Kontrol gruplu bir çalışma}

\author{
Derya Güliz Mert, MD'
}

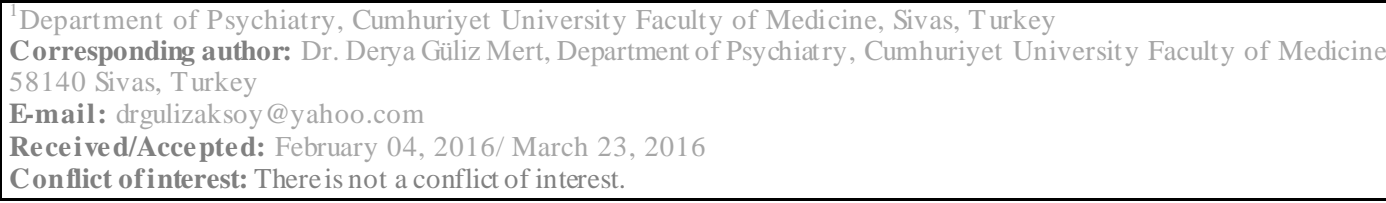

\section{SUMMARY}

Objective: One of the risk factor for different psychiatric disorders has been indicated as hypovitaminosis D. The present study aimed to compare $25(\mathrm{OH}) \mathrm{D}$ level between 4 different types of psychiatric disorders (schizophrenia, bipolar disorder, depression and anxiety disorder) and healthy controls, and to assess the risk factors of hypovitaminosis D in psychiatric inpatients.

Method: This retrospective study included 974 individuals [depression $(n=553)$, bipolar disorder $(n=135)$, schizophrenia $(n=186)$ and anxiety disorder $(n=100)$ ] who received inpatient treatment in psychiatry clinic between 2012 and 2014, and 574 individuals in control group who were not diagnosed with a psychiatric condition. A $25(\mathrm{OH}) \mathrm{D}$ level less than $21 \mathrm{ng} / \mathrm{mL}$ was considered to indicate hypovitaminosis D.

Results: $25(\mathrm{OH})$ D level average of the control group was found to be significantly higher than that of the four psychiatric diagnosis groups $(\mathrm{p}<0.05)$. There was no significant difference among $25(\mathrm{OH}) \mathrm{D}$ level of psychiatric diagnosis groups $(\mathrm{p}<0.05)$. Comparing $25(\mathrm{OH}) \mathrm{D}$ level among age groups in each study group, it was found that $25(\mathrm{OH}) \mathrm{D}$ level of schizophrenic patients with an age range of 35-54 was found to be significantly lower than that of schizophrenic patients with an age range of 18-34 $(\mathrm{p}<0.05) .25(\mathrm{OH})$ D levels by genders were lower among women in all diagnosis groups $(p<0.05)$, while they were similar for both genders in control group $(p>0.05)$. Logistic regression analysis of the study parameters suggested that the female gender (odds ratio: 3.46; 95\% confidence interval: $0.99-1.01$ ), winter and spring seasons (odds ratio: $2.56 ; 95 \%$ confidence interval: $1.69-3.86$ and odds ratio: 2.03 ; $95 \%$ confidence interval: $1.33-3.11$, respectively) were significant predictors in level of vitamin D in psychiatric inpatients.

Conclusions: Hypovitaminosis D is a condition that frequently exists in inpatients in psychiatry clinic suffering from schizophrenia, bipolar disorder, anxiety disorder and depression. Being a female, winter and spring are the most remarkable risk factors in these patients.

Keywords: Hypovitaminosis D, schizophrenia, bipolar disorder, depression, anxiety

\section{ÖZET}

Amaç: Vitamin D eksikliğinin çeşitli psikiyatrik bozukluklar için risk faktörü olabileceği ifade edilmektedir. Bu çalışmada dört farklı psikiyatrik bozukluk (şizofreni, bipolar bozukluk, depresyon, anksiyete bozukluğu) ve sağlıklı kontroller arasında 25(OH)D düzeyini karşılaştırmak ve yatarak tedavi gören psikiyatri hastalarda vitamin D eksiklik nedenleri araştırmak amaçlanmıştır.

Yöntem: Bu retrospektif çalışmaya bir psikiyatri kliniğinde 2012-2014 yılları arasında yatarak tedavi olan 974 birey [depresyon $(n=553)$, bipolar bozukluk $(n=135)$, şizofreni $(n=186)$ ve anksiyete bozukluğu $(\mathrm{n}=100)]$ ve kontrol grubuna psikiyatrik tanıs1 olmayan 574 birey dahil edildi. 
25(OH)D düzeyinin $21 \mathrm{ng} / \mathrm{mL}$ düşük olması vitamin D eksikliği olarak kabul edildi.

Bulgular: Kontrol grubu 25(OH)D düzey ortalaması diğer dört psikiyatrik tanı gruplarının 25(OH)D düzey ortalamasina göre anlamlı olarak yüksek bulundu $(\mathrm{p}<0.05)$. Psikiyatrik tanı gruplarının 25(OH)D düzeyleri arasında ise anlamlı bir fark yoktu $(\mathrm{p}>0.05)$. Her bir çalış̧ma grubunda yaş grupları arasında 25(OH)D düzeyleri karşılaştııldığında 35-54 yaş arası şizofreni hastalarının vitamin D düzeyleri 18-34 yaşrası şizofreni hastalarına göre anlamlı düşük bulundu $(\mathrm{p}<0.05)$. Cinsiyete göre vitamin D düzeyleri tüm tanı gruplarında kadınlarda daha düşük $(\mathrm{p}<0.05)$, kontrol grubunda ise her iki cinsiyette benzer bulundu ( $>0.05)$. Lojistik regresyon analizi ile kadin cinsiyet (odds oranı: 3.46; \%95 güven aralı̆̆: 0.99-1.01), kış ve ilkbahar mevsimleri (sırasıly, odds oran1: 2.56; \%95 güven aralığı: 1.69-3.86 and odds oranı: 2.03; \%95 güven aralı̆̆1: 1.33-3.11) yatan hastalarda vitamin D düzeyini etkileyebilecek parametreler olarak saptandı.

Sonuç: Psikiyatri kliniğinde yatarak tedavi gören şizofreni, bipolar bozukluk, anksiyete ve depresyon hastalarında vitamin D eksikliği sıklikla görülen bir durumdur. Bu hastalarda kadın olma ve kış-ilkbahar mevsimleri vitamin D eksikliği için en önemli risk faktörleri olarak belirlenmiş̧tir.

Anahtar sözcükler: Vitamin D eksikliği, şizofreni, bipolar bozukluk, depresyon, anksiyete

\section{INTRODUCTION}

Vitamin D is an important biochemical agent for nervous system. Possible role of this vitamin in sustaining mental function, as well as brain development has been suggested ${ }^{1}$. Other significant physiological roles of vitamin $\mathrm{D}$ and its involvement in different clinical conditions such as mental disorder have been shown by the evidence gathered in the last decade ${ }^{2-4}$. Development of schizophrenia, cognitive impairment, and depressive symptoms has been associated with vitamin $\mathrm{D}$ deficiency ${ }^{5,6}$. $58 \%$ of psychiatric inpatients were found to have vitamin $\mathrm{D}$ deficiency, while $11 \%$ of psychiatric inpatients had vitamin D levels less than $25 \mathrm{ng} / \mathrm{mL}$, which is lower by $29 \%$ than that of healthy controls ${ }^{7}$. Serum 25-hydroxyvitamin D [25(OH)D] measurement which is obtained either through dietary intake or ultraviolet B (UVB) irradiation of exposed skin is used to assess vitamin D levels. The conversion of vitamin $\mathrm{D}$ to $25(\mathrm{OH}) \mathrm{D}$ takes place in the liver, while its conversion to 1,25-dihydroxyvitamin $\mathrm{D}$, the active form, occurs in kidneys not withstanding its source ${ }^{8}$. There are varying recommendations about the optimal levels of serum vitamin $\mathrm{D}$, but its deficiency level is indicated as $<30 \mathrm{ng} / \mathrm{mL}$, and a serum level lower than $<21 \mathrm{ng} / \mathrm{mL}$ is considered deficient by a number of professional organizations such as The American College of Physicians, and The Endocrine Society 9 .
The role of hypovitaminosis D in psychiatric diseases is gradually attraction attention. Majority of the studies in this field investigate vitamin D deficiency without focusing on the psychiatric diagnosis of psychiatric inpatients ${ }^{5,10,11}$. A limited number of studies attempted to compare vitamin D levels among psychiatric diagnoses ${ }^{12,13}$. However, such studies, relying on very small samples, offer conflicting results about the psychiatric disorder where vitamin $\mathrm{D}$ deficiency is prevalent. Vitamin D deficiency has been indicated among the risk factors of different psychiatric disorders ${ }^{14}$. Thus, the present study attempted to compare vitamin D level between 4 different types of psychiatric disorders (schizophrenia, bipolar disorder, depression and anxiety disorder) and control group, and to assess the risk factors of hypovitaminosis $\mathrm{D}$ in psychiatric inpatients.

\section{METHODS}

Study Design

974 individuals over 18 years of age who were inpatients in psychiatric clinic between 2012 and 2014 were enrolled for this study. 574 individuals over 18 years of age with no psychiatric diagnosis whose serum $25(\mathrm{OH}) \mathrm{D}$ levels were checked in the hospital during the last month were included in the control group. The information whether the individuals in the control group had psychiatric diagnosis was supported by 
the data gathered from the patients, first degree relatives, and patient files. A form designed by the researchers was used to collect socio-demographic variables (age, gender) and clinical variables (psychiatric diagnosis, and the season when the individual was an inpatient in the clinic). Data on this form were gathered from the medical records. The medical records were looked up for those patients who were admitted to the psychiatric hospital with a total serum $25(\mathrm{OH}) \mathrm{D}$ level measured through a laboratory test in 7 days following admission. A $25(\mathrm{OH})$ D level below 21 $\mathrm{ng} / \mathrm{mL}$ was considered to indicate hypovitaminosis $\mathrm{D}^{9}$. In advance of the study, an approval was obtained from the $\mathrm{Hu}-$ man Research Ethics Committee of our university.

\section{Statistics}

The data are presented as the mean \pm SD and percentage as appropriate. Normality was tested using one-sample Kolmogorov-Smirnov test. The ages and averages of $25(\mathrm{OH}) \mathrm{D}$ level of all study groups (depression, bipolar disorder, schizophrenia, anxiety disorder, and control group) were compared through One-way Analysis of Variance (ANOVA). Averages of $25(\mathrm{OH}) \mathrm{D}$ level of age groups for each study group were compared through ANOVA. Where the results of variance analysis indicated a significant difference, the source of difference was investigated through Tukey Test. Chi-square test was used for the comparison of the rates of the gender between all study groups. Vitamin D averages by gender in each study group were compared through student $t$ test. The independent variables believed to affect the dependent variable psychiatric inpatients' 25(OH)D levels, namely age, gender, season and diagnosis, were analyzed by logistic regression test. The level of significance was a $p$ value less than 0.05. We used IBM SPSS Statistics version 22 (IBM Corp., Armonk, NY, USA) for statistical analysis.

\section{RESULTS}

974 individual diagnosed with a psychiatric condition, and 574 who were not diagnosed with such a condition were included in the study. The psychiatric diagnoses were depression $(\mathrm{n}=553)$, bipolar disorder $(\mathrm{n}=135)$, schizophrenia $(\mathrm{n}=186)$ and anxiety disorder $(\mathrm{n}=100)$. Table 1 illustrates the comparison of age, 25(OH)D levels, and gender between the groups. There was no difference in terms of age averages ( $>0.05$ ), but there was difference in terms of gender rates $(\mathrm{p}<0.05)$. The 25(OH)D level average of control group was found significantly higher compared to the $25(\mathrm{OH}) \mathrm{D}$ level average of four psychiatric diagnosis groups $(\mathrm{p}<0.05)$. There was no significant difference between $25(\mathrm{OH}) \mathrm{D}$ levels of psychiatric diagnosis groups (p>0.05) (Table 1)

Table 1. The comparis on of age and gender, and $25(\mathrm{OH}) \mathrm{D}$ levels by study groups

\begin{tabular}{|l|l|l|l|l|l|}
\hline & $\begin{array}{l}\text { Depression } \\
(\mathrm{n}=553)\end{array}$ & $\begin{array}{l}\text { Bipolar Disor- } \\
\text { der } \\
(\mathrm{n}=135)\end{array}$ & $\begin{array}{l}\text { Schizophrenia } \\
(\mathrm{n}=186)\end{array}$ & $\begin{array}{l}\text { Anxiety disorders } \\
(\mathrm{n}=100)\end{array}$ & $\begin{array}{l}\text { Control group } \\
(\mathrm{n}=574)\end{array}$ \\
\hline Age & $37.8 \pm 13.1$ & $37.7 \pm 11.6$ & $38 \pm 11$ & $34.6 \pm 12.6$ & $37.3 \pm 14.6$ \\
\hline $\begin{array}{l}\text { Gender } \\
\text { Female } \\
\text { Male }\end{array}$ & $\begin{array}{l}360(65.1 \%) \\
193(34.9 \%)\end{array}$ & $\begin{array}{l}74(54.8 \%) \\
61(45.2 \%)\end{array}$ & $\begin{array}{l}63(33.9 \%) \\
123(66.1 \%)\end{array}$ & $\begin{array}{l}56(56 \%) \\
44(44 \%)\end{array}$ & $\begin{array}{l}325(56 \%) \\
246(43.4 \%)\end{array}$ \\
\hline 25(OH)D level & $15.5 \pm 8.8$ & $14.9 \pm 7.0$ & $14.7 \pm 7.6$ & $14.4 \pm 8.0$ & $21.1 \pm 9.7^{\mathrm{a}}$ \\
\hline $\begin{array}{l}\text { The data are presented as mean } \pm \text { SD and percentages. } \\
{ }^{\mathrm{a}} \text { Significantly higher compared to other diagnosis groups }(\mathrm{p}<0.05) .\end{array}$ \\
\hline
\end{tabular}


Table 2. Distribution of $25(\mathrm{OH}) \mathrm{D}$ level averages of psychiatric diagnosis and control groups by age groups

\begin{tabular}{|l|l|l|l|l|l|}
\hline & $\begin{array}{l}\text { Depression } \\
(\mathrm{n}=553)\end{array}$ & $\begin{array}{l}\text { Bipolar Disorder } \\
(\mathrm{n}=135)\end{array}$ & $\begin{array}{l}\text { Schizophrenia } \\
(\mathrm{n}=186)\end{array}$ & $\begin{array}{l}\text { Anxiety disorders } \\
(\mathrm{n}=100)\end{array}$ & $\begin{array}{l}\text { Control group } \\
(\mathrm{n}=574)\end{array}$ \\
\hline 18 -34 ages & $14.5 \pm 7.4$ & $15 \pm 6.4$ & $16.8 \pm 8.5$ & $14.2 \pm 6.6$ & $21.3 \pm 19.6$ \\
\hline $35-52$ ages & $16.4 \pm 9.3$ & $14.8 \pm 7.6$ & $12.6 \pm 6.1^{\mathrm{a}}$ & $15.3 \pm 10.1$ & $19.6 \pm 10.4$ \\
\hline 53 and over & $15.8 \pm 10.4$ & $15.7 \pm 7.2$ & $16.3 \pm 6.9$ & $11.1 \pm 3.5$ & $18.8 \pm 8.8$ \\
& & & & \\
\hline
\end{tabular}

Table 2 shows serum 25(OH)D levels among the age categories, which were also used in the study by Humble et al. ${ }^{15}$ and McCue et al. ${ }^{16}$. 25(OH)D levels were compared between age groups for each study group. There was significant difference between age groups only in schizophrenic patients $(p<0.05)$. The difference was found between age groups 18-34 and 35-54. Vitamin D levels of schizophrenic patients between ages 35 and 54 were significantly lower compared to schizophrenic patients between ages 18 and 34 (Table 2).

It is clear from Table 3 that $25(\mathrm{OH}) \mathrm{D}$ levels by gender is lower in females in all diagnoses groups $(\mathrm{p}<0.05)$, while it is similar in both genders in control group ( $>>0.05)$.

Table 3. Distribution of $25(\mathrm{OH}) \mathrm{D}$ level averages of psychiatric diagnosis and control group by gender.

\begin{tabular}{|l|l|l|l|l|l|}
\hline & $\begin{array}{l}\text { Depression } \\
(\mathrm{n}=553)\end{array}$ & $\begin{array}{l}\text { Bipolar Disorder } \\
(\mathrm{n}=135)\end{array}$ & $\begin{array}{l}\text { Schizophrenia } \\
(\mathrm{n}=186)\end{array}$ & $\begin{array}{l}\text { Anxiety disor- } \\
\text { ders } \\
(\mathrm{n}=100)\end{array}$ & $\begin{array}{l}\text { Control group } \\
(\mathrm{n}=574)\end{array}$ \\
\hline Female & $14.6 \pm 8.9^{\mathrm{a}}$ & $12.6 \pm 6.1^{\mathrm{b}}$ & $12.9 \pm 7.8^{\mathrm{c}}$ & $12.7 \pm 7.8^{\mathrm{d}}$ & $21.2 \pm 11.2$ \\
\hline Male & $17.1 \pm 8.2$ & $17.9 \pm 9.4$ & $15.6 \pm 7.3$ & $16.5 \pm 7.9$ & $20.9 \pm 7.3$ \\
\hline $\begin{array}{l}\text { The data are presented as mean } \pm \text { SD. } \\
\text { a,b,c,d } \text { significantly lower for each diagnosis group compared to male gender }(\mathrm{p}<0.05) .\end{array}$ \\
\hline
\end{tabular}

Table 4. Logistic regression analysis revealed that female gender and winter and spring seasons were the variables having significant effect on $25(\mathrm{OH}) \mathrm{D}$ level

\begin{tabular}{|l|l|l|l|}
\hline & Significance & Odds ratio & $95 \%$ Confidence interval \\
\hline Female & 0.001 & 3.46 & $0.99-1.01$ \\
\hline Winter & 0.001 & 2.56 & $1.69-3.86$ \\
Spring & 0.01 & 2.03 & $1.33-3.11$ \\
\hline
\end{tabular}

Logistic regression analysis of the study parameters listed in Table 4 suggested that the female gender (odds ratio: 3.46 ; 95\% confidence interval: $0.99-1.01)$ and winter and spring (odds ratio: 2.56; $95 \%$ confidence interval: 1.69-3.86 and odds ratio: $2.03 ; 95 \%$ confidence interval: 1.33-3.11, respectively) were significant 
predictors of level of vitamin D in psychiatric inpatients.

\section{DISCUSSION}

It was found that $25(\mathrm{OH}) \mathrm{D}$ level of each psychiatric diagnosis group (schizophrenia, bipolar disorder, depression and anxiety disorder) was lower compared to control group included in this study. However, 25(OH)D levels of each psychiatric diagnosis groups were similar. Considering 25(OH)D levels in each diagnosis group by age groups, it was found that only middle-age group (35-52 ages) in schizophrenic patients had low level of $25(\mathrm{OH}) \mathrm{D}$ compared to young age group. In all diagnosis groups except control group, females had lower 25(OH)D level compared to males. Particularly in psychiatric inpatients, it was found that female gender, and winter and spring seasons were factors negatively affecting $25(\mathrm{OH}) \mathrm{D}$ level.

It was observed that $25(\mathrm{OH}) \mathrm{D}$ level in several mental disorders were lower compared to healthy controls ${ }^{17,18}$. Mental disorders that are heavily researched in this matter are depression and schizophrenia. The fact that the symptoms of depression could be reduced with light therapy by increasing vitamin D synthe$\operatorname{sis}^{19,20}$, and that the mood in healthy individuals during winter improved through vitamin $\mathrm{D}$ therapy ${ }^{21,22}$ have focused the attention on the relationship between depression and vitamin D. It is believed that such a relationship could be bidirectional. Due to the decrease of functionality in patients with depression, the time spent at home might increase. This might lessen sun exposure, which might lead to low level of $25(\mathrm{OH}) \mathrm{D}^{23,24}$. On the other hand, vitamin D is believed to play a role in serotonin activity. Vitamin $D$ deficiency and insufficiency have been associated with clinically significant depressive symptoms ${ }^{25,26}$. In this study, we found $25(\mathrm{OH}) \mathrm{D}$ level of patients with depression lower compared to control group. Since this current study is a retrospective one, prospective studies to be conducted might highlight this bidirectional relationship. This bidirectional relationship is also true for schizophrenia and vitamin D. In the event of schizophrenic disorder, an apparent decrease occurs in daily functionality and withdrawal in prodromal period. This might decrease exposure to sunlight, which might consequently lead to a decrease in $25(\mathrm{OH}) \mathrm{D}$ level. On the other hand, there are several studies demonstrating the likely contribution of vitamin D deficiency to development of schizophrenia. Besides being shown with animal experiments, it was emphasized that low and high levels of vitamin $\mathrm{D}$ in newborns could be linked to development of schizophrenia in adulthood $^{6,27}$. It was found that each psychiatric disorders included in this study had lower $25(\mathrm{OH}) \mathrm{D}$ level compared to control groups, and there was no difference among psychiatric diseases. There are conflicting results in the literature on the question that in what psychiatric disorder hypovitaminosis D is more prominent. Belzeaux et al. ${ }^{12}$ reported that they found lower levels of vitamin D in mood disorders compared to schizophrenia in their study. Itzhaky et al. ${ }^{17}$ found in their study that hypovitaminosis $\mathrm{D}$ is more prominent in schizophrenic patients compared to patients with depression. Moreover, in the meta-analysis of Belvederi Murri et al. ${ }^{28}$ and in the study of Schneider et al. ${ }^{13}$, it was found that 25(OH)D levels between these two disorders were similar. The cause of this contradiction could be attributed to the small number of samples included in the study, and to the fact that vitamin D was considered deficient at different values, and to the existing geographic and cultural variability of the patients included. In contrast to other studies, the present study evaluates $25(\mathrm{OH}) \mathrm{D}$ levels in anxiety disorder and bipolar disorder by comparing the levels with those of diagnosis groups and controls group. Although there are reports about the link between vitamin $\mathrm{D}$, and depression and schizophrenia, there have been limited number of studies published indicating the relationship between anxiety disorders or bipolar disorder with the levels of vitamin $\mathrm{D}^{29}$. Some of such studies go as far as arguing that no relationship exists between vitamin D deficiency and anxiety or stress $^{30}$. Yet, in the present 
study, we found lower levels of $25(\mathrm{OH}) \mathrm{D}$ levels in anxiety disorder group compared to control group. Anxiety disorders were addressed as a general diagnosis. It can be considered that addressing subtypes of anxiety disorders would contribute more to the assessment of the relationship between anxiety and vitamin D. Similarly, the present study did not assess the disorder by attack type. To the best of our knowledge, there are no studies in the literature assessing vitamin $\mathrm{D}$ levels according to attack types. Addressing the relationship between attack type (manic-depressivemix) and vitamin D might contribute to detailing the pathogenesis of bipolar disorder.

Population-based studies found a relationship between low serum 25(OH)D concentration, and winter season, obesity, old age, current smoking, physical inactivity, and low dietary intake of vitamin $\mathrm{D}^{8,16,31-33}$. Since the present study is in retrospective order, it was not possible to obtain clear information about smoking habits, bodyweight measurements, dietary intake of vitamin $D$ and physical inactivity of the patients, and thus such elements were not included in the evaluation. Ages were grouped for each diagnosis group, and it was found that middle-age group in schizophrenia had lower levels of vitamin $\mathrm{D}$ compared to the young age group. An association has been indicated between increased age and vitamin $\mathrm{D}$ deficiency. Yet, no difference was found with the older group in this study. Due to the inclusion of a limited number of elderly patients, it is not possible to conduct a valid comparison between schizophrenic patients in the elderly age group. Nevertheless, it is only possible to speculate about the reason why middle-age schizophrenic patients are more prone to having vitamin $\mathrm{D}$ deficiency. It could be possible that the lifestyle of middle-age patients involves less exposure to sunlight, and what they eat contain less vitamin D compared to younger patients. A limited number of studies have assessed the link between vitamin $\mathrm{D}$ deficiency and gender. However in the present study, we found that females in all psychiatric diagnosis groups interestingly had lower levels of vitamin D compared to males. This could be attributed to the fact in Anatolia region of Turkish society women spend more time at home and fail to have more exposure to sunlight. Assessing the relationship between vitamin $\mathrm{D}$, and age, gender, season and psychiatric diagnosis through logistic regression analysis, we found that female gender, winter and spring seasons affected vitamin D levels. The significance of season was emphasized in several other studies beside the present one ${ }^{34,35}$.Particularly, the significance comes to forefront since the amount of sun exposure the individual has is affected by seasons.

Major strengths of this study include the inclusion of sufficiently large sample size compared to several studies and assessment of more psychiatric diagnosis groups. Moreover, the inclusion of control group made a great contribution to understanding and assessing $25(\mathrm{OH}) \mathrm{D}$ level in psychiatric disorders. There are also some limitations of the present study. The first of such is that the association indicated by retrospective study does not certainly point out causality. Moreover, this study might not indicate long-term status since it assessed serum vitamin D concentrations just at certain a point in time. Besides, structured diagnostic rating scales were not used to determine the diagnoses. Finally, we could not clearly specify an adequate level of $25-(\mathrm{OH}) \mathrm{D}$ and optimal ways of assaying this level. Although it was suggested by some experts that a higher cutoff value should be used to determine deficiency, others hold that a lower value should be used. Consequently, the rates we used for deficiency might be considered higher or lower according to the definition of deficiency.

\section{CONCLUSION}

Vitamin D deficiency is a condition frequently occurring in schizophrenia, bipolar disorder, anxiety and depression inpatients in psychiatric clinic. The most remarkable risk factors for vitamin D deficiency in such patients are being a female, and winter and spring seasons. 


\section{Acknowlegments}

I would like to thank Hatice Terzi for invaluable help with the subjects that participated in the study.

\section{REFERENCES}

1. Eyles DW, Smith $\mathrm{S}$, Kinobe R, Hewison M, McGrath JJ. Distribution of the vitamin $\mathrm{D}$ receptor and 1 alpha-hydroxylase in human brain. J Chem Neuroanat 2005; 29: 21-30.

2. Eyles DW, Burne TH, McGrath JJ. Vitamin D, effects on brain development, adult brain function and the links between low levels of vitamin D and neuropsychiatric disease. Front Neuroendocrinol 2013; 34: 47-64.

3. Nesby-O'Dell S1, Scanlon KS, Cogswell ME, Gillespie C, Hollis $\mathrm{BW}$, Looker $\mathrm{AC}$, Allen $\mathrm{C}$, Doughertly C, Gunter EW, Bowman BA. Hypovitaminosis $\mathrm{D}$ prevalence and determinants among African American and white women of reproductive age: third National Health and Nutrition Examination Survey, 1988-1994. Am J Clin Nutr 2002; 76: 187-92.

4. Tangpricha V, Pearce EN, Chen TC, Holick MF. Vitamin D insufficiency among free-living healthy young adults. Am J Med. 2002 Jun 1;112(8):659-62.

5. Leedahl DD, Cunningham JL, Drake MT, Mundis CB, Kung S, Frye MA, Lapid MI. Hypovitaminosis D in psychiatric inpatients: clinical correlation with depressive symptoms, cognitive impairment, and prescribing practices. Psychosomatics 2013; 54: 257-62.

6. McGrath JJ, Burne TH, Féron F, Mackay-Sim A, Eyles DW. Developmental vitamin $\mathrm{D}$ deficiency and risk of schizophrenia: a 10-year update. Schizophr Bull 2010; 36: 1073-8.

7. Berk M, Jacka FN, Williams LJ,
$\mathrm{Ng} \mathrm{F}$, Dodd S, Pasco JA. Is this $\mathrm{D}$ vitamin to worry about? Vitamin D insufficiency in an inpatient sample. Aust N Z J Psychiatry. 2008; 42: 874-8.

8. Holick MF. Vitamin D deficiency. N Engl J Med 2007; 357: 266-81.

9. Holick MF, Binkley NC, Bischoff-Ferrari HA, Gordon CM, Hanley DA, Heaney RP, Murad $\mathrm{MH}$, Weaver CM; Endocrine Society. Evaluation, treatment, and prevention of vitamin D deficiency: an Endocrine Society clinical practice guideline. $\mathbf{J}$ Clin Endocrinol Metab 2011; 96: 1911-30.

10. Zeng Q, Dellenbaugh T, Maldonado $\mathrm{M}$, Moon J, Hornstra R. Vitamin D status of psychiatric inpatients at a community teaching hospital in the Midwest. Nord J Psychiatry 2015; 18:1-7. [Epub ahead of print]

11. Rylander M, Verhulst S. Vitamin D insufficiency in psychiatric inpatients. J Psychiatr Pract 2013;19: 296-300.

12. Belzeaux R, Boyer L, Ibrahim el C, Féron F, Leboyer M, Fond G. Mood disorders are associated with a more severe hypovitaminosis D than schizophrenia. Psychiatry Res 2015; 30; 229: 613-6.

13. Schneider B, Weber B, Frensch A, Stein J, Fritz J. Vitamin D in schizophrenia, major depression and alcoholism. $\mathbf{J}$ Neural Transm (Vienna). 2000;107: 839-42.

14. Parker G, Brotchie H. 'D' for depression: any role for vitamin D? 'Food for Thought' II. Acta Psychiatr Scand. 2011; 124: 243-9.

15. Humble MB, Gustafsson S, Bejerot S. Low serum levels of 25hydroxyvitamin D (25-OHD) among psychiatric out-patients in Sweden: relations with season, age, ethnic origin and psychiatric diagnosis. J Steroid Biochem Mol Biol 2010; 121: 
467-70.

16. McCue RE, Charles RA, Orendain GC, Joseph MD, Abanishe JO. Vitamin d deficiency among psychiatric inpatients. Prim Care Companion CNS Disord. 2012; 14 (2).

17. Itzhaky D, Amital D, Gorden K, Bogomolni A, Arnson Y, Amital H. Low serum vitamin D concentrations in patients with schizophrenia. Isr Med Assoc J 2012; 14: 88-92.

18. Milaneschi Y, Hoogendijk W, Lips P, Heijboer AC, Schoevers $\mathrm{R}$, van Hemert AM, Beekman AT, Smit JH, Penninx BW. The association between low vitamin $\mathrm{D}$ and depressive disorders. Mol Psychiatry 2014; 19: 444-51.

19. Mawer EB, Berry JL, SommerTsilenis E, Beykirch W, Kuhlwein A, Rohde BT. Ultraviolet irradiation increases serum 1,25-dihydroxyvitamin $\mathrm{D}$ in vitamin-D-replete adults. Miner Electrolyte Metab 1984; 10: 117-21.

20. Stumpf WE, Privette TH. Light, vitamin $D$ and psychiatry. Role of 1,25 dihydroxyvitamin D3 (soltriol) in etiology and therapy of seasonal affective disorder and other mental processes. Psychopharmacology (Berl) 1989; 97: 285-94.

21. Lansdowne AT, Provost SC. Vitamin D3 enhances mood in healthy subjects during winter. Psychopharmacology (Berl). 1998 Feb;135(4):319-23.

22. Edström DW, Linder J, Wennersten G, Brismar K, Ros AM. Phototherapy with ultraviolet radiation: a study of hormone parameters and psychological effects. J Eur Acad Dermatol Venereol 2010; 24: 403-9.

23. Anglin RE, Samaan Z, Walter SD, McDonald SD. Vitamin D deficiency and depression in adults: systematic review and meta-analysis. Br J Psychiatry. 2013; 202: 100-7.

24. Penckofer S, Kouba J, Byrn M,
Estwing Ferrans C. Vitamin D and depression: where is all the sunshine? Issues Ment Health Nurs. 2010; 31: 385-93

25. Kerr DC, Zava DT, Piper WT, Saturn SR, Frei B, Gombart AF. Associations between vitamin D levels and depressive symptoms in healthy young adult women. Psychiatry Res 2015; 227: 4651.

26. Kjærgaard $M$, Waterloo $K$, Wang $\mathrm{CE}$, Almås $\mathrm{B}$, Figenschau Y, Hutchinson MS, Svartberg J, Jorde R. Effect of vitamin D supplement on depression scores in people with low levels of serum 25-hydroxyvitamin D: nested case-control study and randomised clinical trial. Br J Psychiatry 2012; 201: 360-8.

27. Burne TH, Becker A, Brown J, Eyles DW, Mackay-Sim A, McGrath JJ. Transient prenatal Vitamin D deficiency is associated with hyperlocomotion in adult rats. Behav Brain Res 2004; 154: 549-55.

28. Belvederi Murri M, Respino M, Masotti M, Innamorati M, Mondelli V, Pariante C, Amore M. Vitamin D and psychosis: mini meta-analysis. Schizophr Res 2013; 150: 235-9

29. Bičíková M, Dušková M, Vítků J, Kalvachová B, Řípová D, Mohr P, Stárka L. Vitamin D in anxiety and affective disorders. Physiol Res 2015; 64 Suppl 2: S101-3.

30. Black LJ, Jacoby P, Allen KL, Trapp GS, Hart PH, Byrne SM, Mori TA, Beilin LJ, Oddy WH. Low vitamin D levels are associated with symptoms of depression in young adult males. Aust N Z J Psychiatry. 2014; 48: 46471

31. Tunstall-Pedoe $\mathrm{H}$, Woodward M, Hughes M, Anderson A, Kennedy G, Belch J, Kuulasmaa K; MORGAM Investigators. Prime mover or fellow traveller: 25-hydroxy vitamin D's seasonal variation, cardiovascular disease 
and death in the Scottish Heart Health Extended Cohort (SHHEC). Int J Epidemiol 2015; 44: 1602-12.

32. Brot C, Jorgensen NR, Sorensen $\mathrm{OH}$. The influence of smoking on vitamin $\mathrm{D}$ status and calcium metabolism. Eur J Clin Nutr 1999; 53: 920-6.

33. Scragg R, Camargo CA Jr. Frequency of leisure-time physical activity and serum 25hydroxyvitamin $\mathrm{D}$ levels in the US population: results from the Third National Health and $\mathrm{Nu}-$ trition Examination Survey. Am J Epidemiol 2008; 168: 577-86.

34. Nanri A, Mizoue T, Matsushita Y, Poudel-Tandukar K, Sato M, Ohta M, Mishima N. Association between serum 25hydroxyvitamin D and depressive symptoms in Japanese: analysis by survey season. Eur $\mathbf{J}$ Clin Nutr 2009; 63: 1444-7.

35. Dana-Alamdari L, Kheirouri S, Noorazar SG. Serum 25Hydroxyvitamin D in Patients with Major Depressive Disorder. Iran J Public Health 2015; 44: 690-7. 